\title{
Two new species of moths (Lepidoptera, Pyralidae, Chrysauginae) associated with the three-toed sloth (Bradypus spp.) in South America
}

\author{
J. D. Bradley (')
}

\begin{abstract}
Two species of chrysaugine moths, discovered as a result of an ecological study in Brazil of tree sloths and their ectoparasites, are described as new and named Cryptoses waagei $\mathrm{sp} . \mathrm{n}$. and C. rufipictus $\mathrm{sp}$. n. They are differentiated from their single congener $\mathbf{C}$. choloepi Dyar and near relatives Bradypophila garbei lhering and Bradypodicola hahneli Spuler which are also found on tree sloths.
\end{abstract}

Several species of pyralid moths of the subfamily Chrysauginae have long been known to live habitualiy in the fur of tree sloths in South America. The moths were generally believed to be parasites and to inhabit the fur of the animal throughout their life-cycle. It is only comparatively recently, in a report by Waage \& Montgomery (1976) based on an ecological study of the moth Cryptoses cholcepi Dyar, which occurs in Costa Rica, Panama and Colombia, and the three-toed sloth Brady. pus variegatus (=infuscatus), that factual evidence on the moth-sloth relationship has become available. The relationship proved to be phoretic, since only in the adult stage (imago) does the moth actually live in the animal's fur. The immature stages of the moth (ovum, iarva, pupa) were found not to live on the animal but on its dung, the larva being coprcphagous (see also Waage \& Best, 1982, for review) .

Subsequently, when ecological studies were extended to Brazil, it was observed that the moths living on the three-toed sloth (Bra. dypus tridactylus and B. variegatus) occurring there differed significantly from $C$. choloepi in certain characteristics. Taxonomic study of the Brazilian specimens, together with material in the collections of the British Museum (Natural History), has shown that two distinct species are involved which are closely related and apparently congeneric with $C$. choloepi but hitherto undescribed.

Cryptoses Dyar, 1908

Cryptoses waagei sp. $\mathrm{n}$.

(Figs. 1-4)

WINGSPAN : $\hat{o}, \stackrel{\imath}{13-15} \mathrm{~mm}$. Sexual dimorphism not pronounced, female usually larger, sexes similar in coloration and forewing pattern, with antennae shortly ciliate, flagellum of male somewhat stouter. Labial palpus, head, thorax, patagium and tegula ochreous. brown, variably suffused with grey-brown; antennal scape and flagellum ochreous-white, scaiing of flageilum in male confined mainly to basal part. In both sexes torewing long and narrow, with apex produced and pointed and termen very oblique; ground colour ochreouswhite, marked with somewhat diffuse longitudinal streaks or rays consisting of black and grey-black scales mixed with dull purplish red scales, comprising basically a subcostal, a medial and a subdorsal streak, these more or less confluent in basal area of wing. diverging distally and interrupted before termen by a narrow band of ground colour, the subcosta! streak divided into two plumes and the medial streak into four plumes postmedially; a series of 5 or 6 blackish interneural dots dispersed along termen; cilia grey, with a diffuse. blackish brown subbasal line. Hindwing uniform!y dark grey, the scaling rather thinspread; cilia unicolorous, with a blackish brown subbasal line. Legs ochreous-white, irrorate or diffusely marked with blackish brown exteriorly. Abdomen ochreous-brown, darker ventraily; male with a light ochreous-brown anal tuft.

IMALE Genitalia: Uncus conical and sparsely setose, its apex reaching well beyond

(1) - Commonwealth Institute of Entomology, c/ British Museum (Natural History) Cromwell Road, London SW7 5BD. 


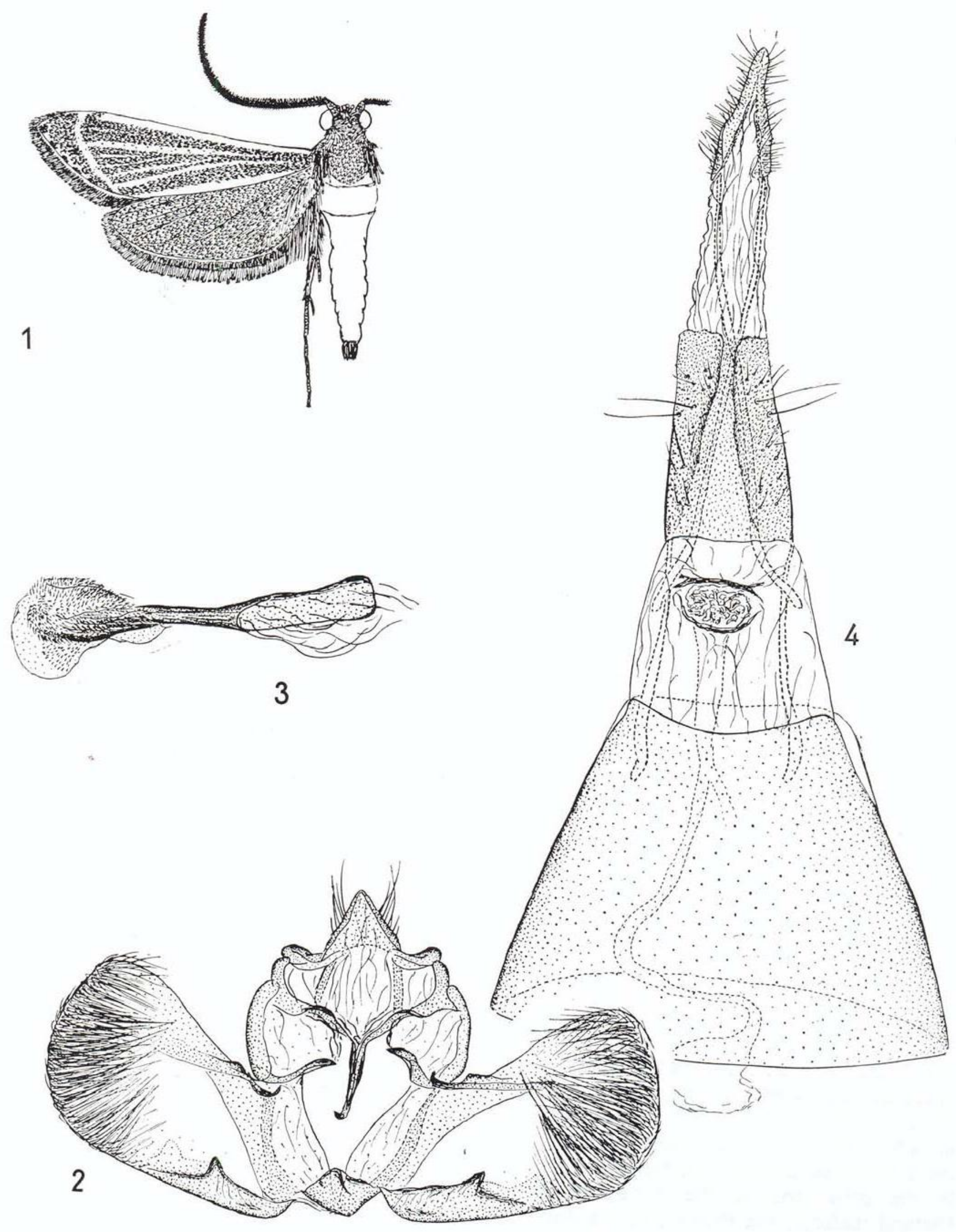

Figs. 1-4-Cryptoses waagei sp. n.: 1, imago, ô:; 2, male genitalia, ventral aspect (aedeagus removed); 3 , aedeagus lateral aspect; 4 , female genitalia, ventral aspect. 
comparatively small lateral protuberances at base. Gnathos with medial process long and slender, hook-tipped. Valva comparatively short and broad, truncated distally; sacculus narrow, reaching to about middle of ventral margin of valva, its uppei (dorsal) margin sharply produced at about middle. Aedeagus with membranous apical part (vesica) minutely spiculate. basal part without internal sclerotization.

FEMALE GENITALIA: Ovipositor extensile, pointed, with Icbes (papillae anales) long and narrow. Eighth sternite long and comparatively slender; ostium situated anteriorly (on intersegmentai membrane), ovate (wider thanbroad); sterigma forming a thin, weakly sclerotized rim; ductus bursae and bursa copulatrix very weakly developed, membranous.

\section{MATERIAL EXAMINED}

HоLотүре $\hat{o}$ : Brazil, Upper Amazon, Codajas, iv.1907 (S.M. Klages); abdomen in situ. Paratypes: Brazil, Manaus, xi.1919 (Parish) $1 \&$ (genitalia slide 13933); Manaus, 12.iv. 1978, ex Bradypus sp. (J. K. Waage), 4 ô (genitalia slide 13887), 1 \% (genitalia slide 13891); Manaus, 19.iii.1978, ex Bradypus sp. (R.C. Best), 1 \%; same locaiity data but dated 27.iii.1978, 1 ô ; ditto 28.iii.1978, 1 ô, 1 우; ditto 8.vi.1979, 1 ô; Parintins, 1.x.1919 (Parish), 1 \& (wing slide 13921, abdomen missing); Rio Japurá, lago Amanã, 2.ix.1979, at light (R.C. Best), 2 ô ; same locality data but dated 10.ix.1979, 3 ô. Holotype and 9 paratypes deposited in the British Museum (Natural History); 8 paratypes in the Museum of Zoology of the University, São Paulo: Museu Paraense Emílio Goeldi, Belém, and Instituto Nacional de Pesquisas da Amazônia, Manaus.

\section{Cryptoses rufipictus $\mathrm{sp} . \mathrm{n}$.}

(Figs. 5-9)

WINGSPAN: ô $11-12 \mathrm{~mm}$, क $15-18 \mathrm{~mm}$ Sexual dimorphism moderately pronounced, female larger and with general coloration of forewing darker; antennae shortly ciliate in both sexes. Labial palpus, head, thorax, pata- gium and tegula greyish ochreous, palpus sprinkled with dark purplish red exteriorly, vertex and frons of head suffused with brownish red. In both sexes forewing moderately broad, with apex obtusely rounded and termen moderately oblique; ground colour cream, in male overlaid with greyish ochreous weakly tinged with olive, in female overlaid with brownish ochreous or reddish ochreous lacking olive tinge but often with an admixture of scattered blackish-tipped scales, except (in both sexes) for poorly defined, slightly convex and sinciate antemedian and postmedian transverse lines, each line arising from a black spot on costa, the spots being heaviest and most conspicuous in the male and the transverse lines often obscure and obliterate, while in the female the postmedian line is often comparatively clear and distinct; in both sexes a few raised blackish scales in upper part of cell a little beyond antemedian line, sometimes forming a stigma in male; costa narrowly edged with orange-yellow sparsely sprinkled with black; blackish interneural dots along termen; cılia cream-white, with a purplish red basal line reaching from apex to near tornus, the reddish coloration infusing the area around the interneural dots along terminal margin. Cilia around tornus wholly suffused with grey. Hindwing uniformly dark grey; cilia creamwhite, with a dark grey subbasal line, sometimes faintly suffused with purplish red from apex to middile of termen, thence suffused with grey. Underside of hindwing grey, with costal margin broadly suffused with purplish red and sprinkled with black; a pair of closely approximated, almost parallel, blackish subterminal lines, the inner one heaviest. Legs pare ochreous, tibia extensively suffused with purplish red exteriorly except tarsal segments, these marked with blackish annuli. Abdomen greyish dorsally, pale ochreous mixed with purplish red ventrally, with a pale ochreous anal tufí.

MALE GENITALIA: Uncus conical and sparsely setose, rather low, its apex reaching only a little beyond comparatively large lateral protuberances. Gnathos with medial process long and slender, hook-tipped. Valva elongated, rounded distally; sacculus short, reaching a 

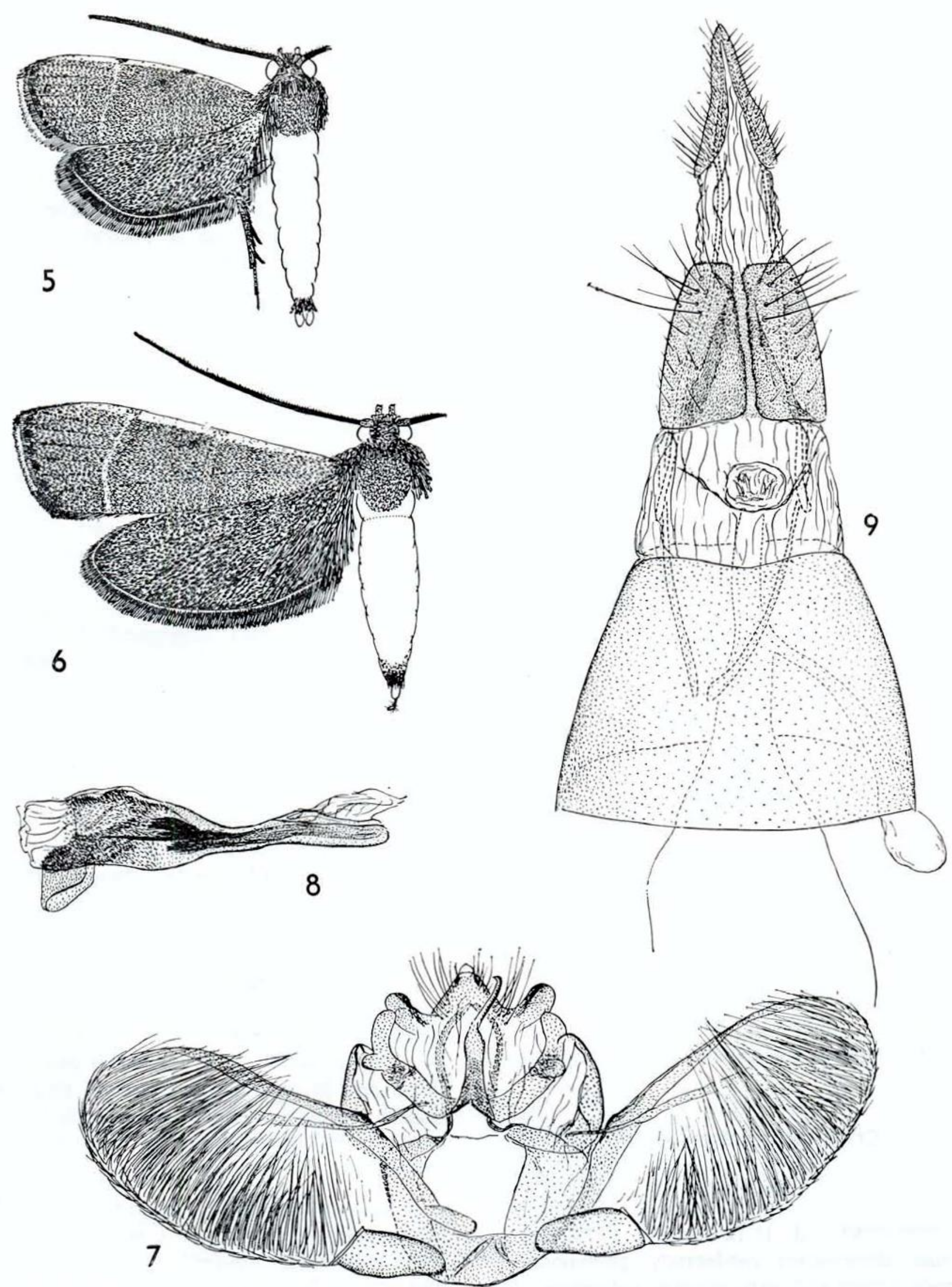

Figs. 5-9-Cryptoses rufipictus sp. n.: 5, imago, $\hat{\sigma} ; 6$, imago, $\$$; 7 , male genitalia, ventral aspect (aedeagus removed); 8 , aedeagus, lateral aspect; 9 , female genitalia, ventral aspect. 
quarter to one third along ventral margin, its inner edge smooth and even. Aedeagus with membranous apical part (vesica) minutely spiculate, basal part strongly sclerotized internally, terminating apically in a long acicular process (cornutus).

FEMALE GENITALIA : Ovipositor extensile slender, pointed, with lobes (papillae anales) long and narrow. Eighth sternite comparatively broad; ostium situated anteriorly (on intersegmental membrane), circular; sterigma membranous posteriorly, weakly sclerotized anteriorly and forming a thin rim. In some specimens examined the ostium bursae had become impregnated with an opaque spherica! mass of black mould spores.

\section{MATERIAL EXAMINED}

HOLOTYPe $\delta$ : French Guiana, St Jean de Maroni, ante 1939 (E. Le Moult); abdomen in situ. Paratypes: same data as holotype, 9 ô (genitalia slides 13911, 13915, 13916), 20 ㅇ (genitalia slides 13909, 13914); Brazil, R. Maroni, - 1916 (Le M.), 1 \% (genitalia slide 13910); Manaus, xi.1919 (Parish), 1 ô; Manaus, 18.i.1978, ex Bradypus sp. (R.C. Best), $1 \mathrm{o}$; same locality data but dated 23.i.1978, 1 \%; ditto 28.i.1978, 2 ㅇ ; ditto 19.iii.1978, 1 \%; ditto 26.iii.1978, 1 \%; ditto 27.iii.1978, 4 रे,2\%; ditto 28.iii.1978, 2 \%; ditto 12.iv.1978, $3 \hat{\sigma}$ (genitalia slide 13886), 3 \& (genitalia slide 13890); Belém, 21.vi.1978, ex Bradypus sp. (R.C. Best), $3 \hat{o}$ (genitalia slide 13888), 4 ㅇ (genitalia slides 13892, 13934); Rio Japurá. Lago Amanã, 2.ix.1979, at light (R.C. Best), $20 \hat{\text {; }}$ same locality data but dated 10.ix.1979, $3 \hat{\sigma}$. Holotype and 46 paratypes deposited in the British Museum (Natural History); 17 paratypes in the Museum of Zoology of the University, São Paulo, Museu Paraense Emílio Goeldi, and Instituto Nacional de Pesquisas da Amazônia, Manaus.

\section{COMMENTS AND DIFFRENTIAL DIAGNOSES}

The imago of $C$. waagei is superficially very similar but on average smaller than that of $C$. choloepi Dyar; the male of the latter can have a wingspan of as little as $13 \mathrm{~mm}$ but is more often nearer $15-17 \mathrm{~mm}$, while the female can reach $24 \mathrm{~mm}$. Both species have a forewing pattern consisting of radiating longitudinal streaks, but $C$. waagei is distinguished by the well-defined subterminal band which in $C$. choloepi is poorly defined and hardly determinate in the male and obliterated in the female, and by the distinct lightcoloured costal margin of the forewing which in C. choloepi is suffused with brown. C. rufipictus differs markedly from both species in having antemedian and postmedian transverse lines on the forewing in lieu of the longitudinal streaks and subterminal band of the other two species.

\section{VENATION}

(Figs. 10-15)

In both $C$. waagei (Figs. 10, 11) and $C$. rufipictus (Figs. 12, 13) vein 11 of the forewing is absent in the male but present in the female, similarly as in C. choloepi (Figs. 14, 15). In C. waagei and C. choloepi veins 3,4 and 5 of the forewing are stalked in both sexes, but in $C$. rufipictus they are stalked in the female only and are either connate or closely approximate in the male. In the hindwing, the stalking of veins 7 and 8 varies in all three species but the stalk is usually longer in $C$. choloepi.

\section{MALE GENITALIA}

The comparatively short valva and promi. nent tooth-like projection from the inner margin of the sacculus distinguish $C$. waagei from $C$. rutipictus. In $C$. cholvepi the valva is comparatively short as in $C$. waagei but differs in having the ciistal margin distinctly rounded rather than truncate, and although the sacculus reaches to near the middle of the ventral margin as in C. waagei it lacks the tooth-like projection. The short plate-like sacculus distinguishes $C$. rufipictus from the other two species. In both $C$. waagei and $C$. rufipictus the uncus is simple and sparsely setose, but in $C$. choloepi it is bifurcate and densely setose apically. 

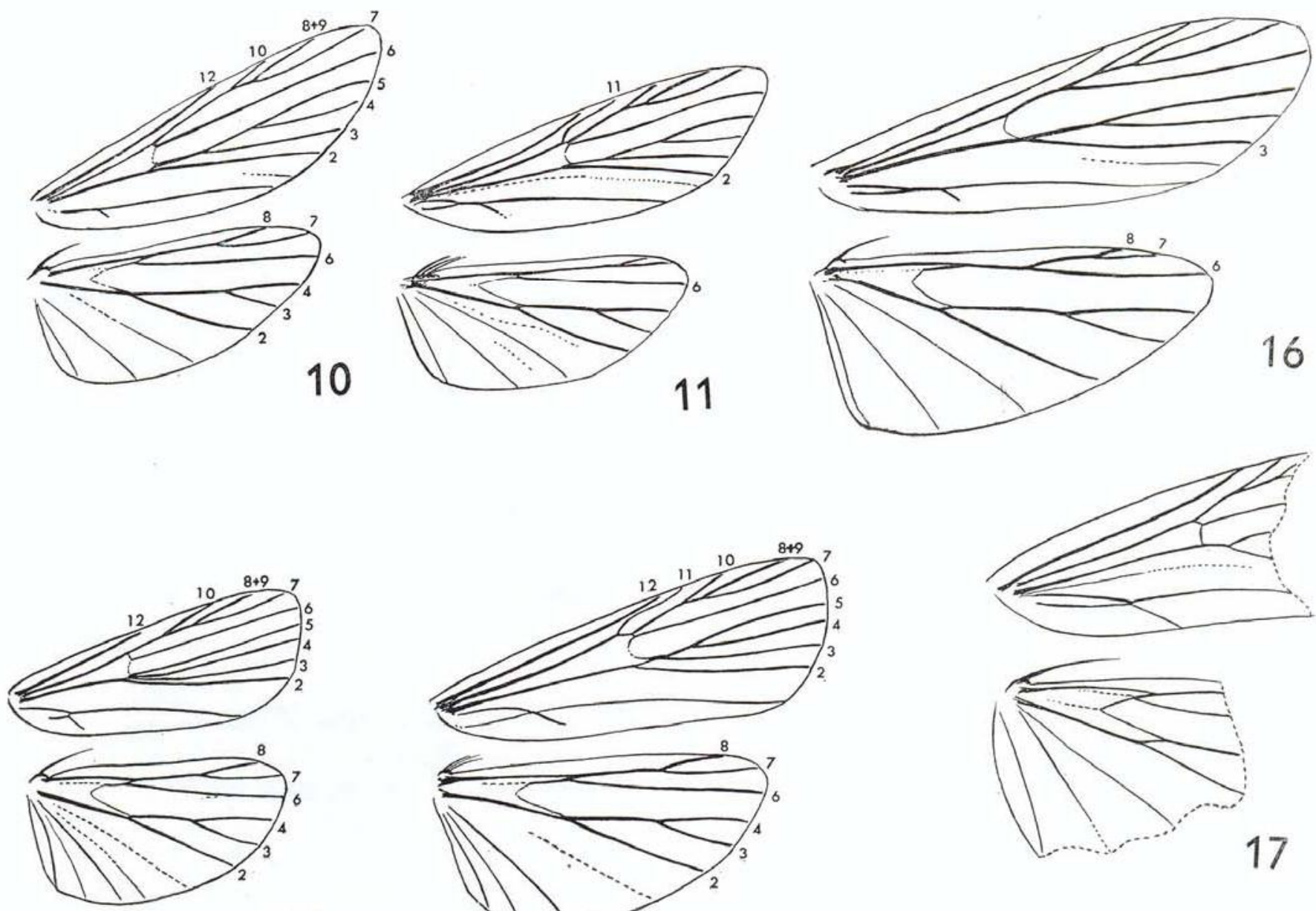

12
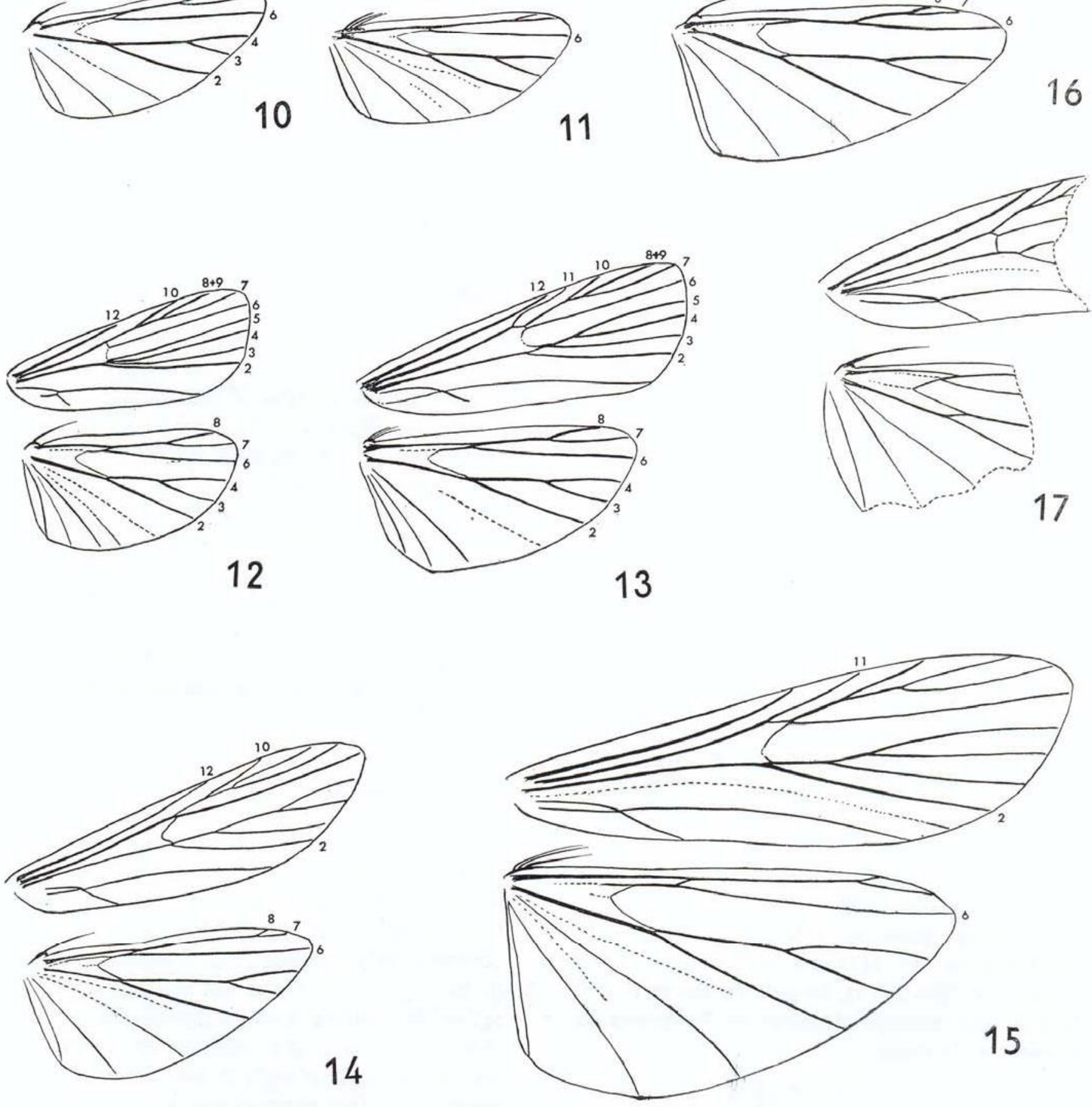

Figs. 10-17 - Wing venation: 10, Cryptoses waagei sp. n., $\delta ; 11$, C. waagei sp. n., $ᄋ ; 12$, Cryptoses rufipictus sn.

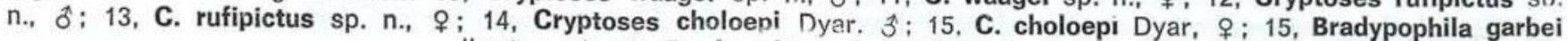
lhering, $\delta$ : 17 , Bradypodicola hahneli Spuler, $\delta$. 


\section{FEMALE GENITALIA}

The structure of the female genitalia in all three species is very similar and differences are mainly comparative. In $C$. choloepi the eighth sternite is relatively short and is less well sclerotized than in the other two species; the ostium is membranous and circular as in C. rufipictus but is relatively larger. C. waagei differs from both species by its broader, ovate ostium.

\section{OTHER CHRYSAUGINAE ASSOCIATED WITH} TREE SLOTHS

Two further chrysaugine species, Bradyphila garbei Iheririg and Bradypodicola hahneli Spuler, are known to live in association with tree sloths in Brazil and adjacent countries in South America. The imagos of both species come within the size-range of the three Cryptoses species but can be distinguished by the following characters.

$B$. garbe i is distinctive by its almost unicolorous dark ochreous forewings, which lack the markings found in Cryptoses. The wing venation (Fig. 16) is reduced and simplified. vein 2 being absent in the forewing and the stalk of veins 7 and 8 anastomosing with vein 6 in the hindwing. As in the genus Cryptoses, vein 11 of the forewing is absent in the male but present in the female.

B. hahneli differs from all the species mentioned above by its almost unicolorous dark fuscous forewings, the coloration being distinctiy more blackish than in B. garbei. A distinctive feature of $B$. hainneli is the com. pressed form of the head, the frons of which is flattened and receding and the vertex prominent; in Cryptoses and Bradypophila the frons is convex and the vertex is not prominent.

In both $B$. hahneli and B. garbei the proboscis is shorter than in Cryptoses and is less extensively scaled at the base and the labial palpi are comparatively rough-scaled and droop more or less straight downwards. In Cryptoses the proboscis is very long and the basal portion is extensively scaled, the labial palpi appear slender, the scales being appressed, and the palpi are held in a declivent, porrect or slightly recurved position.

As a result of examining extensive slothmoth material it has become apparent that, in contrast to the virtually pristine condition of captured imagos of Cryptoses and B. garbei, specimens of $B$. hahneli are often worn and the extremities of the wings sometimes tattered. It seems that the outer margins and fringes of the wings of this species may be weak and thinly scaled and that they could be damaged by movement through the fur of the sloth.

The male genitalia and wing venations of $B$. garbe $i$ and $B$. hahneli are illustrated by Lima (1949) .

\section{ACKNOWLEDGEMENTS}

I am particularly grateful to Dr. J. K. Waage of Imperiai College Field Station, Silwood Park, Ascot, Berkshire, England, who initially made available for study lepidopterous material collected during field work on sloths in South America, and aiso to Dr. Neison Bernardi of the Museu de Universidade de São Paulo. Brazil, who kindly arranged the loan of type material of Bradypophila garbei for comparative study, and to Mr. Robin C. Best of the Instituto Nacional de Pesquisas da Amazônia, Manaus, Brazil and Dr. J. Adis of the Max Planck Institute of Limnology, Plön, West Germany, both of whom subsequently provided additional sloth-moth material for study.

\section{RESUMO}

Duas espécies de mariposas da família Chrysauginae, descobertas pelos estudos ecológicos da preguiça e seus ectoparasitas no Brasil, são descritas como novas e são denominadas, Cryptoses waagei sp. n. e C. rufipictus $\mathrm{sp}$. n. Estas são diferenciadas da única outra espécie deste gênero, C. choloepi Dyar e das espécies afins, Bradypophila garbei Ilhering e Bradypodicola hahneli Spuler que também são encontrados nas preguiças. 


\section{REFERENCES}

DYAR, H.G.

1907 - A Pyralid inhabiting the fur of the living sloth. In Proc. Ent. Soc. Wash., 9: 142-144.

1908 - A further note on the sloth moth. In: Proc. Ent. Soc. Wash.

LIMA, A. da Costa

1949 - Insetos do Brasil. 6. Lepidoptera 2d part. p. 25-36.
WAAGE, J.K. \& BEST, R.C.

1982 - Arthropod associates of sloths. In: G.G. Montgomery (ed..) The Evolution and Ecology of Sloths, Anteaters and Armadilios (Mammalia: Xenarthra: Edendata). Smithsonian Institute Press. Washington, D.C.

WAAGE, J.K. \& MONTGOMERY, G.G.

1976 - Cryptoses choloepi: A coprophagous moth that live. In: Science, 193: 157-158.

(Aceito para publicaçăo em $26 / 03 / 82$ ) 